\title{
Effects of Production History and Gibberellic Acid on Seed Potatoes
}

\author{
E. Virtanen ${ }^{1}$, Hely Häggman ${ }^{2}$, Yeshitila Degefu ${ }^{1}$, Anna-Liisa Välimaa ${ }^{1} \&$ Mervi Seppänen ${ }^{3}$ \\ ${ }^{1}$ MTT Agrifood Research Finland, Biotechnology and Food Research, Oulu, Finland \\ ${ }^{2}$ Department of Biology, University of Oulu, Oulu, Finland \\ ${ }^{3}$ Department of Agricultural Sciences, University of Helsinki, Helsinki, Finland \\ Correspondence: Elina Virtanen, MTT Agrifood Research Finland, Biotechnology and Food Research, P.O.Box \\ 413, 90014 University of Oulu, Oulu, Finland. Tel: 358-40-8432-562. E-mail: elina.virtanen@mtt.fi
}

\author{
Received: September 9, 2013 Accepted: October 12, 2013 Online Published: November 15, 2013 \\ doi:10.5539/jas.v5n12p145 URL: http://dx.doi.org/10.5539/jas.v5n12p145
}

\begin{abstract}
In the present study effects of production history on tuber sprout, root, stem development and crop yield of seed potato cultivars Fambo and Van Gogh were investigated in the High Grade Area of Finland (64.9 N, 25.4 E). The haulms of seed potatoes were destroyed at the time of flowering (50 days after planting, DAP), three weeks after flowering (75 DAP) and as a control the haulm was left to natural death until harvest (95 DAP). The temperature sum accumulation of the seed potatoes was recorded for the growing season and storage period. In addition, the use of plant hormone gibberellic acid (GA) in sprout control was also investigated.

The results indicated that cultivar properties had a greater effect on the sprouting and crop yield of seed potatoes than production-phased haulm killing or temperature sum accumulation. Haulm killing carried out at three weeks after flowering (75 DAP) accelerated the emergence of both cultivars significantly compared to killing at 50 DAP or 95 DAP. Gibberellic acid (GA) treatments significantly increased the number of sprouts and at lower concentration $(100 \mathrm{mM}) \mathrm{GA}$ increased the number of tubers in the cultivar Fambo. Thus, the timing of haulm killing and in the case of Fambo, GA treatment influenced the characteristics of seed potatoes produced in the present study, revealing methods to improve seed potato production in the northern latitudes.
\end{abstract}

Keywords: Solanum tuberosum L., haulm killing, physiological age, dormancy, storage, sprouting, emergence

\section{Introduction}

Seed potato quality can be measured by the ability to produce sprouts and daughter tubers. In addition to cultivar characteristics, seed quality is affected by production and storage conditions (Daniels-Lake \& Prange, 2007). All these factors affect the physiological characteristics of seed potatoes. The physiological state of tubers can be assessed by accumulated temperature sum, incubation period or by combining chronological age and the incubation period (Caldiz, Fernandez, \& Struik, 2001). Delaplace et al. (2008) consider the physiological age index (PAI) to be suitable for defining the aging of potato tubers. However, it has turned out to be difficult to predict physiological ageing of seed potatoes under different conditions (Johansen, Mollerhagen, \& Haugland, 2008). Even though storage technologies have been developed and sprout inhibitors introduced to control the physiological state (Daniels-Lake \& Prange, 2007) and sprouting, in particular, these attributes are difficult to control when seed potatoes are stored for longer periods (Kleinkopf, Oberg, \& Olsen, 2003). This is the case in seed potato production areas in northern Finland (64.9 N, 25.4 E): the growing season is short (120-180 days) and the storage period is relatively long (6-8 months).

In addition, haulm killing in seed potato production is used to regulate the size of the rapidly developing tubers in order to achieve optimal tuber size distribution for commercial purposes. Haulm killing is often carried out on highly immature plants that may still be flowering and the timing of haulm killing is not synchronized with potato tuber maturation. The effect of haulm killing on the physiological state of seed potatoes cannot be predicted (Brown, Beattie, \& Laurence, 2003) or the sprouting potential of tubers cannot be estimated.

One of the key quality criteria for seed potatoes is sprouting efficiency. Seed potatoes should be managed to allow sprouting at a desired time and in a desired manner (Teper-Bamnolker et al., 2010). Metabolic control of sprouting is especially influenced by the interaction of gibberellins and abscisic acid. Gibberellic acid (GA) has been found effective as an interrupter of dormancy (Salimi, Tavakkol, Hosseini, \& Struik, 2010). Zabrouskov, Mohan Kumar, 
Spychalla, \& Knowles (2002) pointed out the physiological and biochemical factors affecting seed potatoes still require further investigation. Chemical sprout inhibitors may also have phytotoxic effects (Sorce, Lorenzi, Parisi, \& Ranalli, 2005).

It has been observed that sprouting management strategies are especially needed in production conditions where storage lasts several months and the growing season is short. This is especially the case in seed potato production areas in northern Finland where the influence of production history and GA treatment on sprouting control or yielding of seed potatoes have not been investigated before. We hypothesized that management strategies might differ between the cultivars with differing maturing properties. Therefore, in the present study, we investigated the effects of haulm killing as a response to temperature accumulation, and the role of GA in sprouting control on early (Fambo) and middle-late (Van Gogh) maturing cultivars of seed potatoes.

\section{Method}

\subsection{Seed Potato Production}

The seed potatoes were produced in the Tyrnävä-Liminka High Grade Area $\left(64^{\circ} \mathrm{N}, 25^{\circ} \mathrm{E}\right)$ in the coastal area of the Gulf of Bothnia. The early cultivar Fambo and the middle-late cultivar Van Gogh were used in the study. Planting (density/row width: 28/80 cm, Kuppi-Juko, Finland) was conducted between 2 June and 7 June in four separate experimental plots (twelve plots, each comprising four replications). The preparation of field-plots was carried out according to normal cultivation practise: plowing in autumn, seedbed preparation by S-tine harrow and horizontal rotary cultivator (Juko, Finland) in spring. Before planting, soil samples were analysed ( $0.5 \mathrm{M}$ ammonium acetate extraction, $\mathrm{pH} 4.65$ ) and, based on the nutrition level data, $64 \mathrm{~kg}$ of N, $40 \mathrm{~kg}$ of P and $152 \mathrm{~kg}$ of K per hectare were applied (NPK 8-5-19 CCF). The $\mathrm{pH}$ and nutrient contents of soil samples varied between the plots: $\mathrm{pH}$ 6.5-6.6, Ca 1453-1662, P 18.8-22.3, K 89-102, Mg 113-159, Cu 3.5-3.5, Mn 13.6-14.0, Zn 1.1-1.2, S 233-388, Ca/Mg 10.45-12.86. The soil type of the field-plots was medium fine sand and the previous crop was potato. After planting, the days to emergence were recorded and the subsequent developmental stages were documented as defined by Hack et al. (1993). Temperature sums (degree days ${ }^{\circ} \mathrm{C}$ ) were calculated using weather data provided by the Finnish Meteorological Institute, Oulunsalo weather station (64.9 N, 25.4 E). Temperature data (temperature sums, mean temperatures, precipitation) were recorded regularly (a-Weather, AWS -1.04B, Alab, Finland) for each experimental plot from the day of planting to the day of harvest (Table 1). Weed control and plant protection were uniform throughout the plots.

Table 1. The weather data representing temperature sum (degree days ${ }^{\circ} \mathrm{C}$ ), mean temperatures and precipitation data during the experiment. The data has been collected from the official weather station ${ }^{\text {a) }}$ and separately from the four different field plots ${ }^{\text {b) }}$

\begin{tabular}{lllllll}
\hline & $\begin{array}{l}\text { Temperature } \\
\text { sum }^{\text {a) }} \\
{ }^{\circ} \mathrm{C}\end{array}$ & $\begin{array}{l}\text { Temperature } \\
\text { sum } \\
{ }^{\circ} \mathrm{C}\end{array}$ & $\begin{array}{l}\text { Mean } \\
\text { temperature } \\
\text { a) }\end{array}$ & $\begin{array}{l}\text { Mean } \\
\text { temperature } \\
{ }^{\circ} \mathrm{C}\end{array}$ & $\begin{array}{l}\text { Precipitation } \\
\mathrm{mm}^{\mathrm{a})}\end{array}$ & $\begin{array}{l}\text { Precipitation } \\
\mathrm{mm}^{\mathrm{b})}\end{array}$ \\
\hline June & 388 & $359-372$ & 12.1 & $13.5-13.9$ & 35 & 48 \\
July & 823 & $712-743$ & 18.5 & $16.4-17.2$ & 57 & 69 \\
August & 1088 & $994-1006$ & 13.6 & $14.1-14.6$ & 72 & 63 \\
September & 1212 & $1117-1136$ & 8.9 & $8.9-9.1$ & 64 & 40 \\
\hline
\end{tabular}

\subsubsection{Haulm Killing}

Mechanical haulm killing (Grimme crusher, Germany) was conducted, with the foliage cut to approximately 30 $\mathrm{cm}$. Chemical haulm killing (Reglone, diquat dibromide, $200 \mathrm{~g} / 1$ at 3001/ha) was conducted one day after mechanical haulm killing. The experimental design for the haulm killing was as follows: 1) haulm killing at the time of flowering on 22 July, 50 days after planting (50 DAP), 2) haulm killing three weeks after flowering on 14 August (75 DAP). The latter represents the normal time of haulm killing in the High Grade Area, and 3) as a control, the haulm was left to natural maturation until harvest on 2 September (95 DAP).

\subsubsection{Harvesting and Storage}

Harvesting was conducted ten days after haulm killing. The harvested tubers were analysed for nutrient content, weight, starch content, tuber size distribution, and external quality. The tubers were stored temporarily at $+15^{\circ} \mathrm{C}$ 
until the last experimental plot was harvested. On 20 October, the total harvest from all plots was transferred to cold storage $\left(+4^{\circ} \mathrm{C}\right.$, relative humidity $\left.90 \%\right)$. Tubers sized $30-40 \mathrm{~mm}$ were numbered and placed in storage in egg cartons.

Cold storage $\left(+4^{\circ} \mathrm{C}\right)$ temperatures were collected using the minimum and maximum thermometer readings and curves of the thermo-hygrograph (R Fuess Berlin-Steglitz NR. 1387, Germany). The sprouting efficiency of the seed potatoes was observed after 20 and 25 weeks of storage by counting the number of potato eyes and percentage of developed sprouts, and by measuring sprout length (categories: less than $1 \mathrm{~cm}$ and over $1 \mathrm{~cm}$ ). The temperature of the sprouting environment was recorded by an automatic weather station (a-Weather, AWS -1.04B, Alab, Finland).

\subsection{Carry-Over Study}

After 25 weeks of cold storage $\left(+4^{\circ} \mathrm{C}\right)$ and three weeks of pre-sprouting at $+14^{\circ} \mathrm{C}$, the seed potatoes were transferred to a grow tunnel and planted (5 May) in plastic growing boxes $(45 \mathrm{~cm} \mathrm{x} 60 \mathrm{~cm})$ in a peat (Biolan, Novagrow) growing medium. A total of 4,680 tubers were studied (195 tubers per lot x 3 haulm killings $\times 4$ replications x 2 cultivars). The plants were irrigated mechanically with a liquid fertilizer (Nutri S-A $0.5 \%$ solution). The temperature of the grow tunnel was recorded by an automatic weather station (a-Weather, AWS -1.04B, Alab, Finland).

The emergence dates of each individual plant were noted and the developmental stages observed according to Hack et al. (1993) with potential foliage symptoms recorded at one week intervals. Harvesting was carried out on 19 August (106 DAP). The number and fresh and dry weight of the stems and roots and the number, fresh weight, starch content and external quality of the tubers were assessed individually.

\subsection{Gibberellic Acid Treatment}

The effect of the plant hormone gibberellins (GA) on seed potato sprout development and yielding capacity was examined by immersing seed potatoes taken from cold storage in two concentrations (100 $\mathrm{mM}$ and $400 \mathrm{mM})$ of gibberellic acid (Sigma-Aldrich, G7645-5G, Germany) solution with one-minute water treatment as a control. After these treatments, the seed potatoes were allowed to sprout at $+14^{\circ} \mathrm{C}$ for three weeks before planting. During pre-sprouting the number of sprouts was counted three times. At harvest, the number and weight of stems and tubers were determined individually.

\subsection{Statistical Analyses}

The experimental model was a split plot design with main and sub plots. The statistical analyses were conducted using the Mixed procedure of the SAS 9.2 / SAS Enterprise Guide 4.3 (SAS Institute Inc., Cary, NC, USA) program, using a variance analysis model in compliance with the split plot study design.

\section{Results}

\subsection{Seed Potato Production}

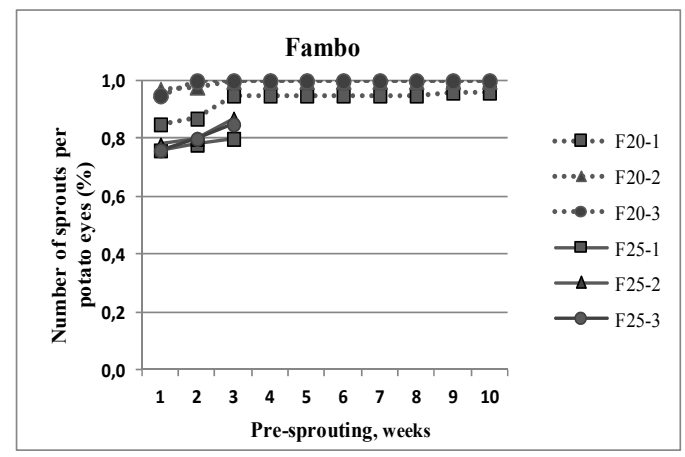

a)

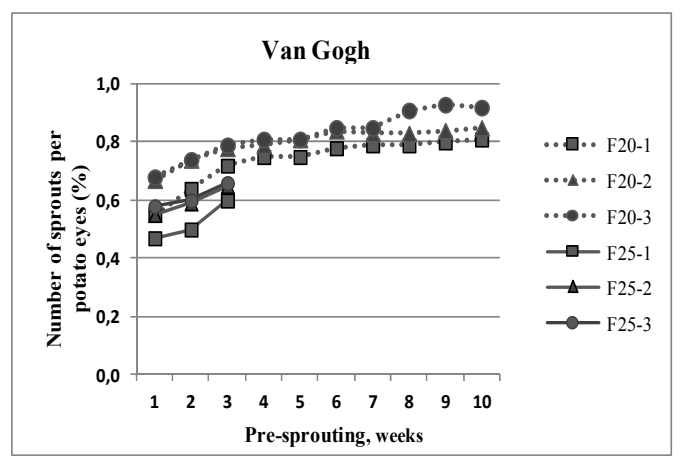

b)

Figure 1. The sprouting efficiency of seed tubers representing cultivars a) Fambo and b) Van Gogh after 20 (...) and $25\left(\_\right.$) weeks of storage. Haulm killing 1( ${ }^{-}$), at the time of flowering on July $22=50$ DAP (days after planting), haulm killing $2(\boldsymbol{\Delta})$, three weeks after flowering on August $14=75$ DAP (triangle) and 3 (•) no haulm killing, natural maturation $=95$ DAP 
The sprouting efficiency of cultivars Fambo $(\mathrm{p}=0.58)$ and Van Gogh $(\mathrm{p}=0.15)$ differed after 20 and 25 weeks in cold storage test. The early cultivar Fambo required only three weeks of sprouting to produce the maximum number of sprouts per potato eye (\%), while Van Gogh required a longer period (Figure 1).

After production, 25 weeks of storage and three weeks of pre-sprouting, the seed potatoes accumulated total temperature sums of $3,198^{\circ} \mathrm{C}(50 \mathrm{DAP}), 3,284^{\circ} \mathrm{C}(75 \mathrm{DAP})$ and $3,336{ }^{\circ} \mathrm{C}(95 \mathrm{DAP})$. Different haulm killing times related to temperature accumulation sums or GA treatments did not result in any significant differences in the number of sprouts after three weeks of pre-sprouting.

\subsection{Carry-Over Effects of Haulm Killing}

Haulm killing affected the emergence of seed potatoes. Seed potatoes whose haulms were destroyed three weeks after flowering (75 DAP) emerged fastest (10.7 days), whereas those seed potatoes whose haulms maturated naturally until harvest (95 DAP) or were destroyed at the time of flowering (50 DAP) emerged more slowly (11.6-12.6 days) (Table 2). With regard to emergence rate, no significant difference was observed between the cultivars.

Haulm killing also affected the root and stem bulk produced. The physiologically older the seed potato, the larger the root and stem bulk at 95 days after planting. Root and stem bulk production was lowest in seed potatoes whose haulm had been destroyed at the time of flowering. The cultivars also differed significantly $(p<0.01)$ with regard to root and stem bulk, with Van Gogh producing the most. Haulm killing had no effect on crop yield or the number of tubers. However, the daughter tubers of naturally maturated seed potatoes had slightly higher starch content (Table 2).

Table 2. Effect of haulm killing and cultivar (Fambo and Van Gogh) on seed potato growth vigour. Haulm killing treatments: 1) haulm killing at the time of flowering (50 DAP = days after planting), 2) haulm killing three weeks after flowering (normal time of haulm killing,75 DAP) and 3) natural maturation, no haulm killing (harvesting at 95, DAP)

\begin{tabular}{|c|c|c|c|c|c|c|c|c|c|c|c|}
\hline & & & & & & \multicolumn{6}{|c|}{ Haulm killing x Cultivar } \\
\hline & \multicolumn{3}{|c|}{ Haulm killing } & \multicolumn{2}{|c|}{ Cultivar } & \multicolumn{3}{|c|}{ Fambo } & \multicolumn{3}{|c|}{ Van Gogh } \\
\hline & 1 & 2 & 3 & Fambo & Van Gogh & 1 & 2 & 3 & 1 & 2 & 3 \\
\hline \multicolumn{12}{|l|}{ Before planting: } \\
\hline No. of all sprouts & 5.8 & 6.0 & 6.1 & $7.1^{* *}$ & $4.8^{* *}$ & 7.2 & 7.0 & 7.2 & 4.5 & 4.9 & 5.1 \\
\hline No. of sprouts $>1 \mathrm{~cm}$ & 1.5 & 1.7 & 1.7 & 1.8 & 1.5 & 1.9 & 2.0 & 1.9 & 1.3 & 1.5 & 1.6 \\
\hline \multicolumn{12}{|l|}{ After planting: } \\
\hline Emergence (DAP) & $12.6^{* * *}$ & $10.7^{* * *}$ & $11.6^{* * *}$ & 11.7 & 11.6 & 11.8 & 10.3 & 11.8 & 12.3 & 11.0 & 11.5 \\
\hline \multicolumn{12}{|l|}{ Harvesting: } \\
\hline No. of stems & 1.7 & 1.9 & 2.1 & 2.2 & 1.7 & 2.2 & 2.2 & 2.2 & 1.4 & 1.7 & 2.0 \\
\hline Fresh wt. of stems (g/plant) & $77^{*}$ & $87 *$ & $119^{*}$ & $49 *$ & $140^{*}$ & 56 & 43 & 56 & 108 & 131 & 182 \\
\hline Dry wt. of stems (g/plant) & $12.1^{*}$ & $12.4^{*}$ & $16.1^{*}$ & $10.5^{*}$ & $16.6^{*}$ & 12.0 & 9.6 & 12.0 & 14.2 & 15.2 & 20.3 \\
\hline Fresh wt. of roots (g/plant) & 30.1 & 27.3 & 29.8 & $18.0^{* *}$ & $40.1 * *$ & 18.7 & 17.0 & 18.7 & 41.9 & 37.5 & 40.8 \\
\hline Dry wt. of roots (g/plant) & $2.57^{*}$ & $2.36^{*}$ & $2.84 *$ & $1.64 * *$ & $3.54 * *$ & 1.68 & 1.56 & 1.68 & 3.45 & 3.16 & 4.01 \\
\hline No. of tubers & 10.6 & 11.7 & 11.3 & 10.5 & 11.9 & 10.1 & 10.9 & 10.1 & 10.6 & 12.5 & 12.6 \\
\hline Fresh wt. of tubers (g/plant) & 552 & 544 & 549 & 545 & 552 & 563 & 530 & 563 & 562 & 559 & 535 \\
\hline Starch content of tubers (\%) & $15.4^{*}$ & $15.0^{*}$ & $16.1^{*}$ & $13.3 * *$ & $17.7^{* *}$ & 13.8 & 12.8 & 13.8 & 17.5 & 17.2 & 18.4 \\
\hline
\end{tabular}

Statistically significant differences between haulm killing treatments or cultivars at $* \mathrm{P}=0.05, * * \mathrm{P}=0.01$ and $* * * \mathrm{P}=0.001$. There were no significant interactions between treatments and cultivars for any of the variables measured.

\subsection{Carry-Over Effects of Gibberellic Acid}

GA treatments increased the number of stems in both cultivars, with a greater effect in Fambo than in Van Gogh $(p=0.001)$, when compared to the control treatment, even though the effect of the treatments was not found in the number of sprouts $(\mathrm{p}=0.21)$. The GA treatments had a negative effect on crop yield ( $\mathrm{g} / \mathrm{plant})$, in particular when the cultivar Fambo was treated with $400 \mathrm{mM} \mathrm{GA}(\mathrm{p}=<0.001)$. Correspondingly, a $100 \mathrm{mM}$ GA concentration 
increased the number of tubers in Fambo, in comparison to water and $400 \mathrm{mM} \mathrm{GA}$ treatment, as presented in Figure 2.
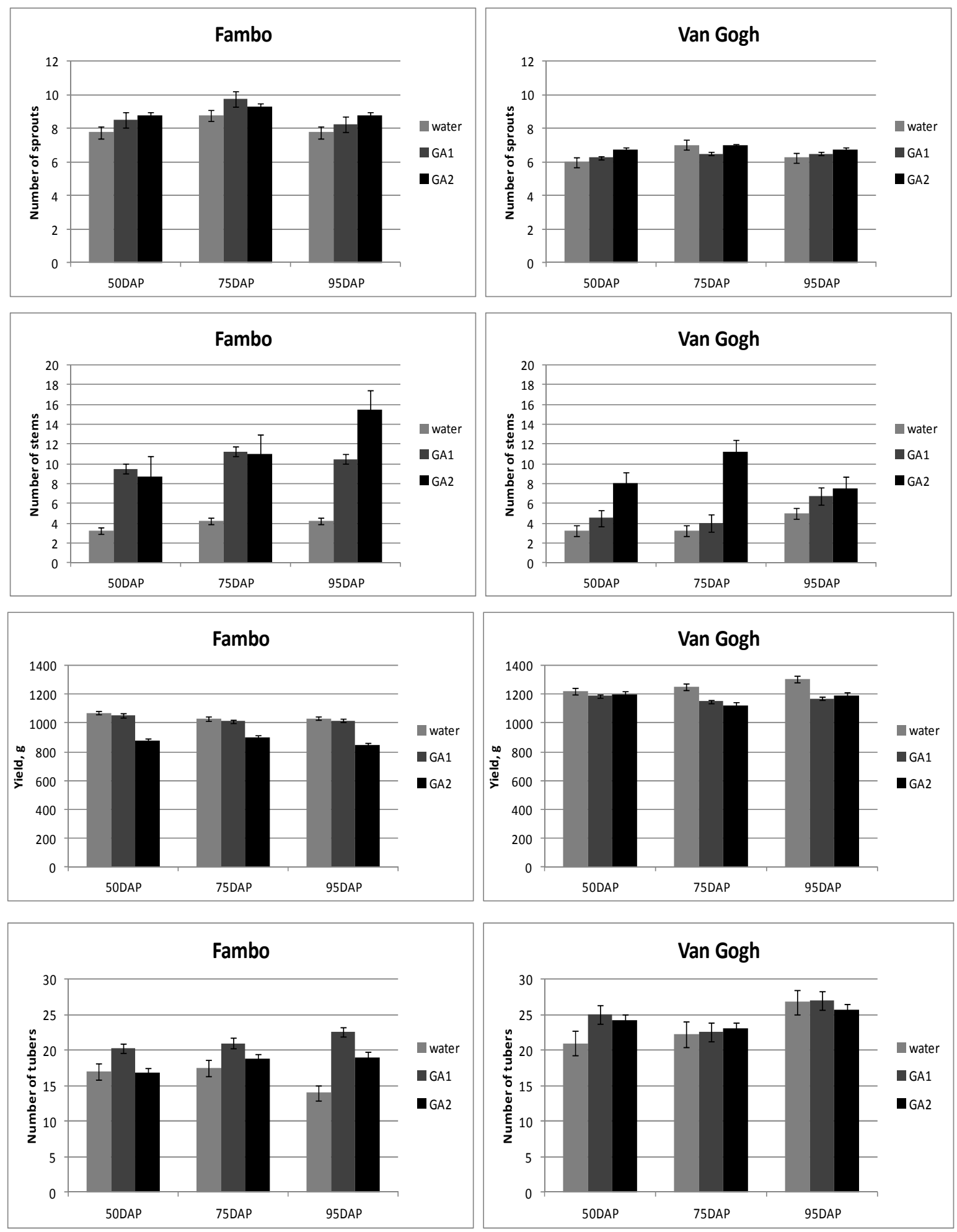

Figure 2. The effect of gibberellic acid (GA) treatments (GA1=100mM, GA2 $=400 \mathrm{mM}$ and water control), conducted before pre-sprouting, on the number of sprouts, stems, tubers and crop of cultivars Fambo and Van Gogh. Haulm killing conducted 50 DAP (day after planting), 75 DAP and 95 DAP (harvesting 95 days after planting, no haulm killing) 


\section{Discussion}

Seed potatoes are generally evaluated based on growth vigour and tuber productivity. In addition to cultivar, these characteristics are influenced by the production history. Northern production conditions (temperature accumulation during the growing season, short growing season, long periods of daylight, and haulm killing), storage conditions (pre-storage 2 weeks $+15^{\circ} \mathrm{C}$, cold storage 25 weeks $+4^{\circ} \mathrm{C}$ ) and pre-sprouting $\left(2\right.$ weeks $+14^{\circ} \mathrm{C}$ ) were evaluated and all of these factors affected the growth and yielding capacity of the seed potatoes.

\subsection{Effect of Production History}

Temperature sum accumulation increases the physiological age of seed potato (O'Brien, Jones, Allen, \& Raouf, 1986). Studies show that physiologically older seed potatoes emerge more quickly than the younger ones (O'Brien et al., 1983; Bodlaender \& Marinus, 1987; Van der Zaag \& Van Loon, 1987; Knowles \& Botar, 1991; Jenkins, Gillison, \& Alsaidi, 1993; Essah \& Honeycutt, 2004; Eremeev et al., 2008). Particularly in short growing season production areas, the quick emergence of seed potatoes accelerates early development of potato growth. Haulm killing or its timing in seed potato production has not previously been observed to have a carry-over effect on the emergence rate of seed potatoes (Holmes \& Gray, 1972). The present study demonstrates that in northern production conditions haulm killing conducted three weeks after flowering (75 DAP) accelerates the emergence of seed potato.

With regard to the number of stems, the results vary. In most studies, older seed potatoes produce more main stems (Iritani, 1968; Iritani \& Weller, 1987; Knowles \& Knowles, 2006), whereas in the studies by Ezekiel (2004), seed potato age had no influence on stem number. The timing of the temperature sum accumulation increases the number of stems in seed potato (Bodlaender \& Marinus, 1987; Jenkins et al., 1993), whereas the growing season temperature and daylength do not influence the numbers of seed potato stems or bulk stems (Johansen, Lund, \& Nilsen, 2002; Johansen \& Nilsen, 2004). In the present study, naturally maturated seed potatoes produced the most bulk stems and roots and showed physiological behaviour similar to old seed potato.

In conditions where the growing season is short, seed potatoes that are older and that have thus experienced a higher temperature sum due to a longer accumulation period are more productive (O'Brien et al., 1983; O'Brien et al., 1986; Knowles \& Botar, 1992; Ezekiel, 2004). Northern origin or daylength do not affect yield capacity (Ezekiel, 1997; Johansen et al., 2002; Knowles \& Knowles, 2006; Johansen et al., 2008). On the other hand, haulm killing affects crop yield; for example, Brown et al. (2003) reported that haulm killing conducted three weeks before natural haulm maturing results in increased yield of seed potatoes. In a study by Panelo and Caldiz (1989), haulm killing two weeks before natural maturing did not affect crop yield. In the present study, haulm killing in seed potato production had no carry-over effects.

The production history of seed potato can affect the size and number of developing tubers. If the growing season is short, old seed potatoes tend to produce larger tubers than seed potatoes at younger physiological state (Jenkins et al., 1993; Johansen et al., 2002; Essah \& Honeycutt, 2004; Eremeev et al., 2008). Growing season temperature has not been observed to have a carry-over effect on the number of daughter tubers produced by seed potato (Johansen et al., 2002; Johansen \& Nilsen, 2004), nor has daylength been found to affect the size of daughter tubers (Johansen et al., 2002). In the studies of Wurr, Fellows, Akehurst, Hambidge, \& Lynn (2001), haulm killing did not influence tuber size, and Holmes and Gray (1972) found no effect of haulm killing on tuber number. The results of the present study are consistent with Holmes and Gray (1972) and Wurr et al. (2001) indicating that haulm killing does not affect the size or number of tubers produced.

\subsection{Effect of Gibberellic Acid}

Salimin et al. (2010) reported that gibberellic acid (GA) was effective in interrupting the dormancy of mini-tubers. However, the sprouts that developed in the GA-treated tubers were easily broken during handling and planting. Other sprouting inhibitors are also effective in interrupting dormancy or sprouting management (Beaver, Devoy, Schafer, \& Riggle, 2003; Bajji, M'Hamdi, Gastiny, Rojas-Beltran, \& du Jardin, 2007; Teper-Bamnolker et al., 2010), but the effects of treatments on seed potatoes have not been studied. Alexopoulos, Aivalakis, Akoumianakis, \& Passam (2008) used GA at a concentration of $1-50 \mathrm{mg} / \mathrm{l}$ and found that treatment duration appears to be more important than GA concentration. In their sprouting management studies, Pruski et al. (2006) discovered that treatment of seed potatoes with ethylene during storage resulted in larger numbers of sprouts and increased the number of tubers, but did not result in higher crop yield. Production and storage conditions (Van Ittersum 1993) as well as carbohydrate metabolism and plant hormones (Daniels-Lake \& Prange, 2007) also influence dormancy. In the present study, GA treatments were in line with the results of Pruskin et al. (2006), i.e.100 mM GA concentration increased the number of tubers in Fambo but did not affect crop yield. 
Sprouting management strategies and methods are particularly needed in production conditions where storage lasts several months and the growing season is short (Veerman \& Wustman, 2005; Daniels-Lake \& Prange, 2007). Even though the metabolism of seed potatoes (dormancy, sprouting management) can be influenced (Struik \& Wiersema, 1999), the effects of production history have to be predicted and managed. In this study, the effect of northern production conditions indicate that the tubers behaved as physiologically young seed potatoes regardless of haulm killing or cultivar properties. Therefore, indicators other than tuber size are needed to determine the preferred timing of haulm killing. Also, the physiological state of tubers designated as seed potatoes should be well known in order to optimize pre-sprouting and the use of sprouting inhibitors. The timing of haulm killing and, in the case of Fambo, GA treatment influenced the characteristics of seed potatoes produced in the present study, revealing a way to improve seed potato production in northern conditions.

\section{References}

Alexopoulos, A. A., Aivalakis, G., Akoumianakis, K. A., \& Passam, H. C. (2008). Effect of gibberellic acid on the duration of dormancy of potato tubers produced by plants derived from true potato seed. Postharvest Biology and Technology, 49, 424-430. http://dx.doi.org/10.1016/j.postharvbio.2008.02.009

Bajji, M., M'Hamdi, M., Gastiny, F., Rojas-Beltran, J. A., \& du Jardin, P. (2007). Catalase inhibition accelerates dormancy release and sprouting in potato (Solanum tuberosum L.) tubers. Biotechnology, Agronomy and Society Environment, 11, 121-131. Retrieved from http://popups.ulg.ac.be/Base/document.php?id=687

Beaver, R. G., Devoy, M. L., Schafer, R., \& Riggle, B. D. (2003). CIPC and 2.6-DIPN sprout suppression of stored potatoes. American Journal of Potato Research, 80, 311-316. http://dx.doi.org/10.1007/BF02854315

Bodlaender, K. B. A., \& Marinus, J. (1987). Effect of physiological age on growth vigour of seed potatoes of two cultivars. 3. Effect on plant growth under controlled conditions. Potato Research, 30, 423-440. http://dx.doi.org/10.1007/BF02361920

Brown, P. H., Beattie, B., \& Laurence, R. (2003). Intergenerational effects on seed potato physiological aging. Acta Horticulture, 619, 241-249.

Caldiz, D. O., Fernandez, L. V., \& Struik, P. C. (2001). Physiological age index: a new, simple and reliable index to assess the physiological age of seed potato tubers based on haulm killing date and length of the incubation time. Field Crops Research, 69, 69-79. http://dx.doi.org/10.1016/S0378-4290(00)00134-9

Daniels-Lake, B. J., \& Prange, R. K. (2007). The canon of potato science: 41. sprouting. Potato Research, 50 , 379-382. http://dx.doi.org/10.1007/s11540-008-9065-6

Eremeev, V., Lõhmus, A., Lääniste, P., Jõudu, J., Talgre, L., \& Lauringson, E. (2008). The influence of thermal shock and pre-sprouting of seed potatoes on formation of some yield structure elements. Acta Agriculturae Scandinavica Section B - Soil and Plant Science, 58, 35-42. http://dx.doi.org/10.1080/09064710601160243

Essah, S. Y. C., \& Honeycutt, C. W. (2004). Tillage and seed-sprouting strategies to improve potato yield and quality in short season climates. American Journal of Potato Research, 81, 177-186. http//dx.doi.org/10.1007/BF02871747

Ezekiel, R. (1997). Effect of environmental and cultural factors during growth of seed potato (Solanum tuberosum) crop on subsequent performance of progeny tubers as seed. Indian Journal of Agricultural Sciences, 67, 447-450.

Ezekiel, R. (2004). The effect of physiological age of potato seed tubers on sprout and plant growth characteristics. Potato Journal, India, 31, 77-80.

Hack, H., Gall, H., Klemke, T., Klose, R., Meier, U., Stauss, R., \& Witzenberger, A. (1993). The BBCH-scale for phonological growth stages of potato (Solanum tuberosum L.), Proceedings of the 12th Annual Congress of the European Association for Potato Research Paris, 153-154.

Holmes, J. C., \& Gray, D. (1972). Carry-over effects of sprouting and haulm destruction in the potato seed crop. Potato Research, 15, 220-235. http://dx.doi.org/10.1007/BF02361809

Iritani, W. M. (1968). Factors affecting physiological aging (degeneration) of potato tubers used as seed. American Potato Journal, 45, 111-116. http://dx.doi.org/10.1007/BF02862871

Iritani, W. M., \& Weller, D. L. (1987). The influence of physiological age, stem numbers and fertility on yield and grade of Russet Burbank potatoes. American Potato Journal, 64, 291-299. http://dx.doi.org/10.1007/BF02853521 
Jenkins, P. D., Gillison, T. C., \& Alsaidi, A. S. (1993). Temperature accumulation and physiological aging of seed $\begin{array}{lllll}\text { potato tubers. Annals of Applied } & \text { Biology, } & \text { 122, }\end{array}$ http://dx.doi.org/10.1111/j.1744-7348.1993.tb04040.x

Johansen, T. J., \& Nilsen, J. (2004). Influence of low growth temperatures on physiological age of seed potatoes. Acta Agriculturae Scandinavica Section B - Soil and Plant Science, 54, 185-188. http://dx.doi.org/10.1080/09064710410035712

Johansen, T. J., Lund, L., \& Nilsen, J. (2002). Influence of daylength and temperature during formation of seed potatoes on subsequent growth and yields under long day conditions. Potato Research, 45, 139-143. http://dx.doi.org/10.1007/BF02736109

Johansen, T. J., Mollerhagen, P., \& Haugland, E. (2008). Yield potential of seed potatoes grown at different latitudes in Norway. Acta Agriculturae Scandinavica Section B - Soil and Plant Science, 58, 132-138. http://dx.doi.org/10.1080/09064710701412635

Kleinkopf, G. E., Oberg, N. A., \& Olsen, N. L. (2003). Sprout inhibition in storage: Current status, new chemistries and natural compounds. American Journal of Potato Research, 80, $317-327$. http://dx.doi.org/10.1007/BF02854316

Knowles, N. R., \& Botar, G. I. (1991). Modelling the effects of potato seed-tuber age on plant establishment. Canadian Journal of Plant Science, 71, 1219-1232. http://dx.doi.org/10.4141/cjps91-170

Knowles, N. R., \& Botar, G. I. (1992). Effect of altering the physiological age of potato seed tubers in the fall on subsequent production in short season environment. Canadian Journal of Plant Science, 72, $275-287$. http://dx.doi.org/10.4141/cjps92-033

Knowles, N. R., \& Knowles, L. O. (2006). Manipulating stem number, tuber set, and yield relationships for Northern- and Southern- grown potato seed lots. Crop Science, 46, $284-296$. http://dx.doi.org/10.2135/cropsci2005.05-0078

O’Brien, P. J., Allen, E. J., Bean, J. N., Griffith, R. J., Jones, S. A., \& Jones, J. L. (1983). Accumulated day degrees as a measure of physiological age and the relationships with growth and yield in potato varieties. Journal of Agricultural Science, Cambridge, 101, 613-631. http://dx.doi.org/10.1017/S002185960003865X

O’Brien, P. J., Jones, J. L., Allen, E. J., \& Raouf, G. S. M. (1986). Effects of physiological age of seed tubers on seed yield and regrowth of progeny tubers in potatoes. Journal of Agricultural Science, 107, $307-327$. http://dx.doi.org/10.1017/S0021859600087116

Panelo, M., \& Caldiz, D. O. (1989). Influence of early haulm killing of seed crops on subsequent sprouting, physiological aging and tuber yield. Potato Research, 32, 3-7. http://dx.doi.org/10.1007/BF02365812

Pruski, K., Prange, R. K., Daniels-Lake, B. J., Nowak, J., Astatkie, T., \& Ronis, D. H. (2006). Growth-room and field studies with seed tubers treated with ethylene and 1-methylcyclopropene (1-MCP) during storage. American Journal of Potato Research, 83, 149-160. http://dx.doi.org/10.1007/BF02872150

Salimi, Kh., Tavakkol A., R., Hosseini, M. B., \& Struik, P. C. (2010). Effects of gibberellic acid and carbon disulphide on sprouting of potato minitubers. Scientia Horticulturae, 124, 14-18. http://dx.doi.org/10.1016/j.scienta.2009.12.026

Sorce, C., Lorenzi, R., Parisi, B., \& Ranalli, P. (2005). Physiological mechanism involved in potato (Solanum tuberosum L.) tuber dormancy and the control of sprouting by chemical suppressants. Acta Horticulture, 684, 177-185.

Struik, P. C., \& Wiersema, S. G. (1999). Seed Potato Technology. The Netherlands: Wageningen Pers.

Teper-Bamnolker, P., Dubai, N., Fischer, R., Belausov, E., Zemach, H., Shoseyov, O., \& Eshel, D. (2010). Mint essential oil can induce or inhibit potato sprouting by differential alteration of apical meristem. Planta, 232, 179-186. http://dx.doi.org/10.1007/s00425-010-1154-5

Van der Zaag, D. E., \& van Loon, C. D. (1987). Effects of physiological age on growth vigour of seed potatoes of two cultivars. 5. Review of literature and integration of some experimental results. Potato Research, 30, 451-472. http://dx.doi.org/10.1007/BF02361922

Van Ittersum, M. K. (1993). Advancing growth vigour of seed potatoes by storage temperature regimes. Netherlands Journal of Agricultural Science, 41, 23-36. http://dx.doi.org/10.1007/BF02848644 
Veerman, A., \& Wustman, R. (2005). Present state and future prospects of potato storage technology. In A. J. Haverkort, \& P. C. Struik (Eds.), Potato in progress: Science meets practice, (pp. 179-189). Wageningen, The Netherlands: Wageningen Academic Publisher.

Wurr, D. C. E., Fellows, J. R., Akehurst, J. M., Hambidge, A. J., \& Lynn, J. R. (2001). The effect of cultural and environmental factors on potato seed tuber morphology and subsequent sprout and stem development. Journal of Agricultural Science, 136, 55-63. http://dx.doi.org/10.1017/S0021859600008431

Zabrouskov, V., Mohan Kumar, G. N., Spychalla, J. P., \& Knowles, N. R. (2002). Oxidative metabolism and the physiological age of the seed potatoes are affected by increased $\alpha$-linolate content. Physiologia Plantarum, 116, 172-185. http://dx.doi.org/10.1034/j.1399-3054.2002.1160206.x

\section{Copyrights}

Copyright for this article is retained by the author(s), with first publication rights granted to the journal.

This is an open-access article distributed under the terms and conditions of the Creative Commons Attribution license (http://creativecommons.org/licenses/by/3.0/). 